\title{
ENVIRONMENTAL AND CLIMATIC CHANGE AS RECORDED IN GEOLOGICAL SEDIMENTS FROM THE ARID TO SEMI-ARID ZONE OF CHINA
}

\author{
Weijian Zhou ${ }^{1,2} \cdot$ Wu Zhengkun $^{1} \cdot$ A J T Jull ${ }^{3} \cdot$ G Burr $^{3}$ • D D Donahue ${ }^{3}$ Li Baosheng ${ }^{4}$. \\ J Head ${ }^{1,5}$
}

\begin{abstract}
Stratigraphic investigations together with climatic proxy data measurements and reliable radiocarbon dating show a history of fluctuations of dry and wet environmental conditions in the arid to semi-arid zone of northern China since the late Pleistocene. Based on these data, we are able to reconstruct shifts of the desert margin in two period extremes, the last glacial maximum (21-15 ka) and the Holocene Optimum (9-5 ka). We have compared the present desert margin with that for the two extremes. The results indicate that a southward shift of the present margin of about 3 degrees in latitude might be caused by anthropogenic impact. Hence the influence of human activity must be taken into consideration for sustainable development and environment protection. Future research will be to find a two-way feedback existing between climate and anthropogenic impacts.
\end{abstract}

\section{INTRODUCTION}

The arid to semi-arid transitional zone is contained within the $200-400 \mathrm{~mm}$ annual precipitation belt. The zone is close to the northern position of the East Asian summer monsoon front, and is very sensitive to changes in humidity (Yie 1992; Zhu et al. 1992; Zhou et al. 1996). The response of the arid to semi-arid zone in China to global change mainly embodies changes between dry and wet conditions. For instance, during global glacial events, loess and eolian sand are deposited under arid conditions. During the global interglacial period, soil or peat has been developed under moist conditions. These types of changes are prevalent within the desert-loess transition zone (the arid to semi-arid transition zone). Hence, local climatic changes can be placed within the context of global change. Dry grassland and shrubs dominate the zone, while forested areas are concentrated mainly along river corridors and deltas. Mobile, semi-mobile, and fixed sand dunes characterize the arid landscape (Zhu et al. 1986). During summer, a steady flow of moist maritime air from the southeast onto the continent produces about $80 \%$ of the annual precipitation (Zhou et al. 1996). Hence, enhanced summer monsoon conditions over time encourage soil formation and vegetation development, resulting in sand dune stability. During winter, a flow of cold, dry air out of north central Asia (winter monsoon) results in a significant flux of eolian sand toward the southeast (An et al. 2000; Zhou et al. 1999). Sandy loess layers found in the Loess Plateau and paleosol sequences found in the sandy desert demonstrate latitudinal shifts of the southern desert margin. The present polar and monsoon fronts are aligned in a northeast to southwest direction, as is the present southern desert margin. Our aims for this research are: 1) to reconstruct the arid to humid history based on reliable dating and proxy data, 2) to improve our understanding of spatial variation within the desert margin during the last 20,000 years, and 3) to assess the anthropogenic impact on the environment.

\footnotetext{
${ }^{1}$ State key laboratory of Loess and Quaternary Geology, Institute of Earth Environment, Chinese Academy of Sciences, PO Box 17, Xi'an 710054, Shaanxi Province, China

${ }^{2}$ Corresponding author. Email: weijian@llqg.ac.cn.

${ }^{3}$ NSF-AMS Facility, University of Arizona, Tucson, Arizona 85721 USA

${ }^{4}$ Department of Geography, Normal University of South China, Guangzhou 510631, China

${ }^{5}$ School of Geosciences, University of Wollongong, North Wollongong, NSW 2522, Australia
}

(C) 2001 by the Arizona Board of Regents on behalf of the University of Arizona Radiocarbon, Vol 43, Nr 2B, 2001, p 619-627

Proceedings of the 17 th International ${ }^{14} \mathrm{C}$ Conference, edited by I Carmi and $\mathrm{E}$ Boaretto 


\section{Geological Record with ${ }^{14} \mathrm{C}$ Dating in the Arid to Semi-Arid Transitional Zone and Its History of Climatic Change over the Last 20,000 Years}

The studied areas and the collected published ${ }^{14} \mathrm{C}$ data have been shown in Figures 1 and 2, and Table 1. The dating materials are peat, soil organic ( $\mathrm{NaOH}$ insoluble), wood cellulose, and pollen. The pretreatment techniques are described elsewhere (Head et al. 1989; Zhou et al. 1997, 1998). The pretreated samples were combusted into $\mathrm{CO}_{2}$, which was reduced to graphite for ${ }^{14} \mathrm{C}$ AMS determinations (Slota et al. 1987). This work was carried out at the NSF-AMS Facility, Physics Department, University of Arizona. A portion of the $\mathrm{CO}_{2}$ from each sample was taken for $\delta^{13} \mathrm{C}$ determinations. The chronological framework for both Shengmu $\left(38^{\circ} 48^{\prime} \mathrm{N}, 110^{\circ} 27^{\prime} \mathrm{E}\right)$ and Jingbian $\left(37^{\circ} 39^{\prime} \mathrm{N}\right.$, $108^{\circ} 37^{\prime} \mathrm{E}$ ) are in sequence. The Shengmu and Jingbian locations can be regarded as representative of the northern Loess Plateau. The Shengmu profile is $4.5 \mathrm{~m}$ thick, consisting of eolian sand and paleosol sequences. Pollen and soil organic AMS ${ }^{14} \mathrm{C}$ dates are shown on the right side of the Stratigraphic column, ranging from 17,300 to $6900 \mathrm{BP}$. The top of the profile has been eroded away. The Jingbian profile is about $7 \mathrm{~m}$ thick, consisting of peat and eolian sand. AMS ${ }^{14} \mathrm{C}$ determinations have been

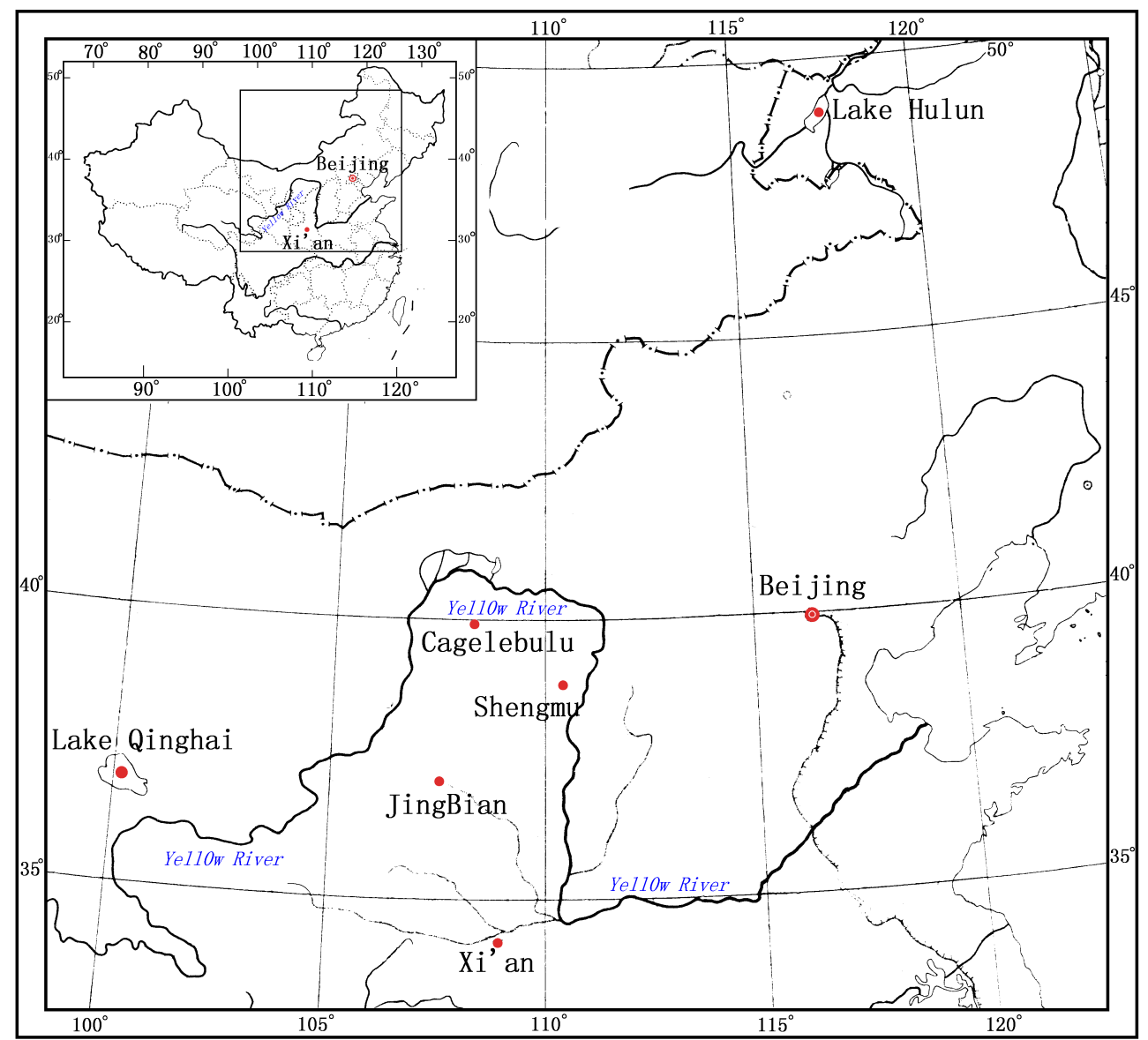

Figure 1 Map of the studied locations. The upper left inset is the map of China. 
obtained from plant residues and charcoal from peat sediment, starting from $3.5 \mathrm{~m}$. The top above 3.5 $\mathrm{m}$ is composed of eolian sand. The Cagelebulu eolian sand and paleosol profile $\left(39^{\circ} 53^{\prime} \mathrm{N}, 108^{\circ} 18^{\prime} \mathrm{E}\right.$; Dong et al. 1995) together with published data from lake Hulun (Wang et al. 1995) and Lake Qinghai (Du et al. 1989) have been chosen as representatives of the desert environment.

We have made proxy measurements at 5-cm intervals as shown in Figure 3. For the Shengmu profile, magnetic susceptibility (SUS) determinations were carried out. It has been argued that the main carrier of the susceptibility signal is ultrafine-grained magnetite produced during in-situ pedogenesis, which can also be linked to summer monsoon precipitation (Maher and Thompson 1991; An et al. 1991). Therefore, there is a positive correlation between the magnetic susceptibility and the atmospheric moisture. The SUS signal is an indicator of the relative summer monsoon intensity (An et al. 1991). For the Jingbian profile, pollen analysis has been carried out. Artemisia/Chenopodiaceae ratios have been calculated as an indicator of moisture (El-Moslimany 1990) in arid to semi-arid areas (the higher the ratio the higher the moisture levels). Organic carbon content has also been widely used as an indicator of vegetation cover and biomass (Hakansson 1985). Combined with pollen analysis, it is possible to reconstruct the environmental vegetation history.

Table $1{ }^{14} \mathrm{C}$ AMS results

\begin{tabular}{lclrr}
\hline Lab nra/sample location & & & & \multicolumn{1}{c}{$\begin{array}{c}\text { Cal. }{ }^{14} \mathrm{C} \text { age } \\
(2 \sigma, \mathrm{BP})\end{array}$} \\
\hline AA12176/Jing Bian, China & 383 & Peat & $3490 \pm 60$ & $3685-3815$ \\
AA12179/Jing Bian, China & 495 & Peat & $5130 \pm 60$ & $5785-5925$ \\
AA12181/Jing Bian, China & 601 & Peat & $7240 \pm 80$ & $7960-8080$ \\
AA16388/Jing Bian, China & 741 & Peat & $9300 \pm 80$ & $10,140-10,340$ \\
AA16689/Jing Bian, China & 817 & Charcoal & $10,025 \pm 80$ & $11,000-11,190$ \\
AA12190/Jing Bian, China & 958 & Wood cellulose & $10,370 \pm 70$ & $11,905-12,495$ \\
AA16390/Jing Bian, China & 1018 & Charcoal & $11,070 \pm 80$ & $12,800-13,170$ \\
AA12317/Sheng Mu, China & 11 & Pollen & $6950 \pm 60$ & $7630-7840$ \\
AA12311/Sheng Mu, China & 22 & Pollen & $7790 \pm 70$ & $8380-8720$ \\
AA16686/Sheng Mu, China & 75 & NaOH insoluble & $8395 \pm 75$ & $9200-9500$ \\
AA12313/Sheng Mu, China & 102 & Pollen & $9030 \pm 70$ & $9880-10,150$ \\
AA16685/Sheng Mu, China & 152 & NaOH insoluble & $9645 \pm 80$ & $10,540-10,980$ \\
XLQG1030/ShengMu, China & 215 & NaOH insoluble & $10,270 \pm 80$ & $11,640-12,745$ \\
XLQG1031/ShengMu, China & 250 & NaOH insoluble & $10,590 \pm 100$ & $12,130-12,950$ \\
AA12326/Sheng Mu, China & 325 & Pollen & $11,250 \pm 80$ & $12,970-13,370$ \\
AA16120/Sheng Mu, China & 425 & Pollen & $17,315 \pm 130$ & $19,910-21,325$ \\
\hline
\end{tabular}

aAA is the lab code of the NSF-AMS facility, University of Arizona, Tucson, USA; XLQG is the code of State Key laboratory of Loess and Quaternary Geology, Chinese Academy of Sciences, China.

From Figures 2 and 3 it can be seen that the arid to semi-arid zone in China can be characterized by high frequency fluctuations during the last deglacial climates. In the last glacial maximum, eolian sand was deposited in the desert, which is the case with the Shengmu profile. In the case of desert lakes, a mixture of sand and gravel was deposited. This reflects the dominance of severe cold and dry climate conditions present during the Last glacial Maximum. The period from 13,000 to 11,000 BP (calibrated age 14,900-12,900 cal BP; Stuiver et al. 1998) is the Bølling/Allerød interstadial. Monsoon precipitation clearly increased in the arid to semi-arid zone (as shown in the Lake Hulun and Beijing sections, Figure 3). High magnetic susceptibility values in the Beijing profile and total 

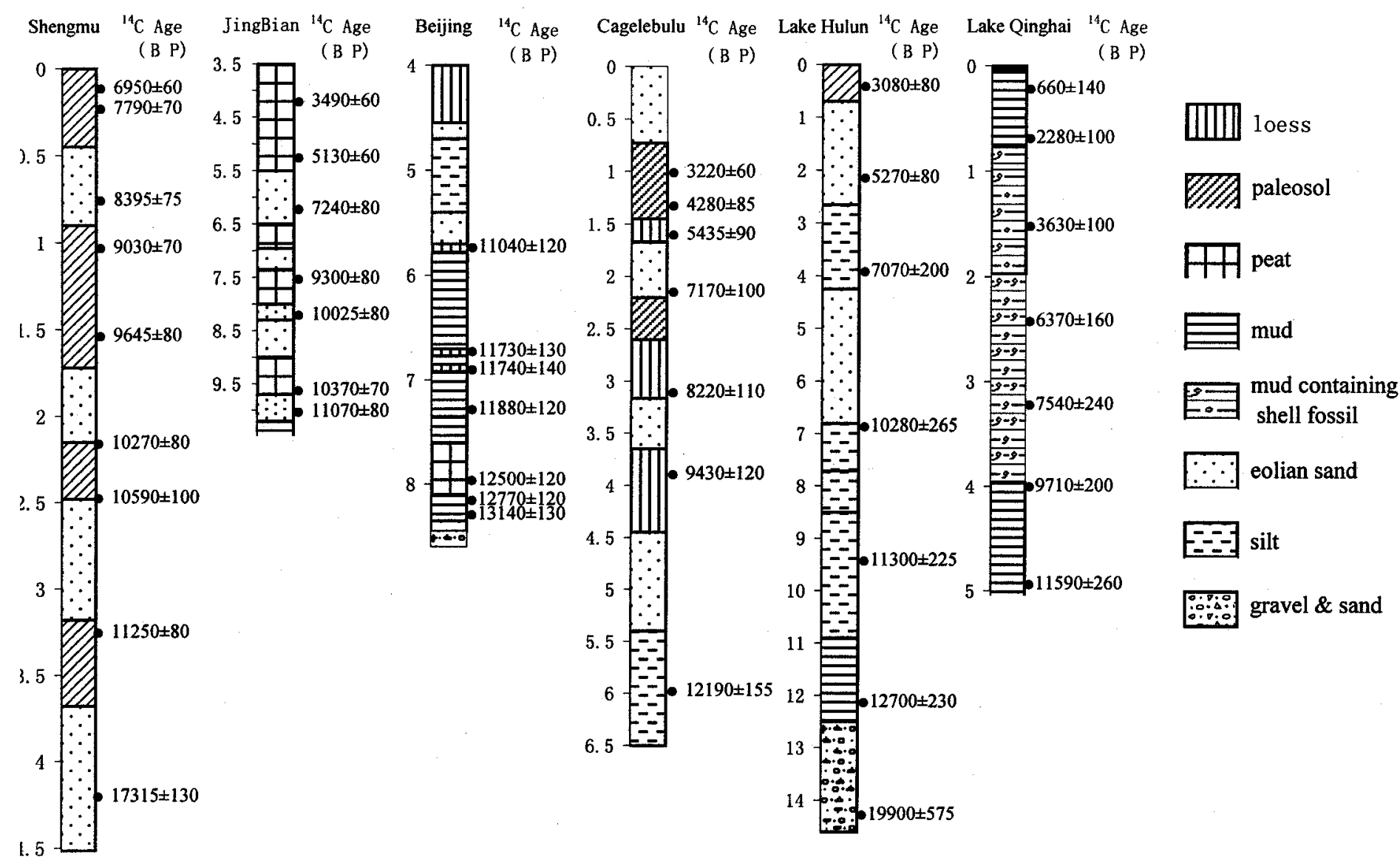

Figure 2 Stratigraphic sequences from profiles at five locations representing the arid to semi-arid zone in China, covering the period from the last 20,000 years to the present. The profiles illustrated are: Shengmu $\left(38^{\circ} 48^{\prime} \mathrm{N}, 110^{\circ} 27^{\prime} \mathrm{E}\right)$, and Jingbian $\left(37^{\circ} 39^{\prime} \mathrm{N}, 108^{\circ} 37^{\prime} \mathrm{E}\right)$, representing the south margin of the desert; Beijing is in the semi-arid zone; Cagelebulu $\left(39^{\circ} 53^{\prime} \mathrm{N}, 108^{\circ} 18^{\prime} \mathrm{E}\right.$; Dong et al. 1995), Lake Hulun $\left(48^{\circ} 31^{\prime}-49^{\circ} 20^{\prime} \mathrm{N}, 116^{\circ} 58^{\prime}-117^{\circ} 48^{\prime} \mathrm{E}\right.$; Wang et al. 1995), and Lake Qinghai $\left(36^{\circ} 15^{\prime}-38^{\circ} 20^{\prime} \mathrm{N}, 97^{\circ} 50^{\prime}-\right.$ $101^{\circ} 20^{\prime} \mathrm{E}$; Research Center 1994) representing the inland desert. 


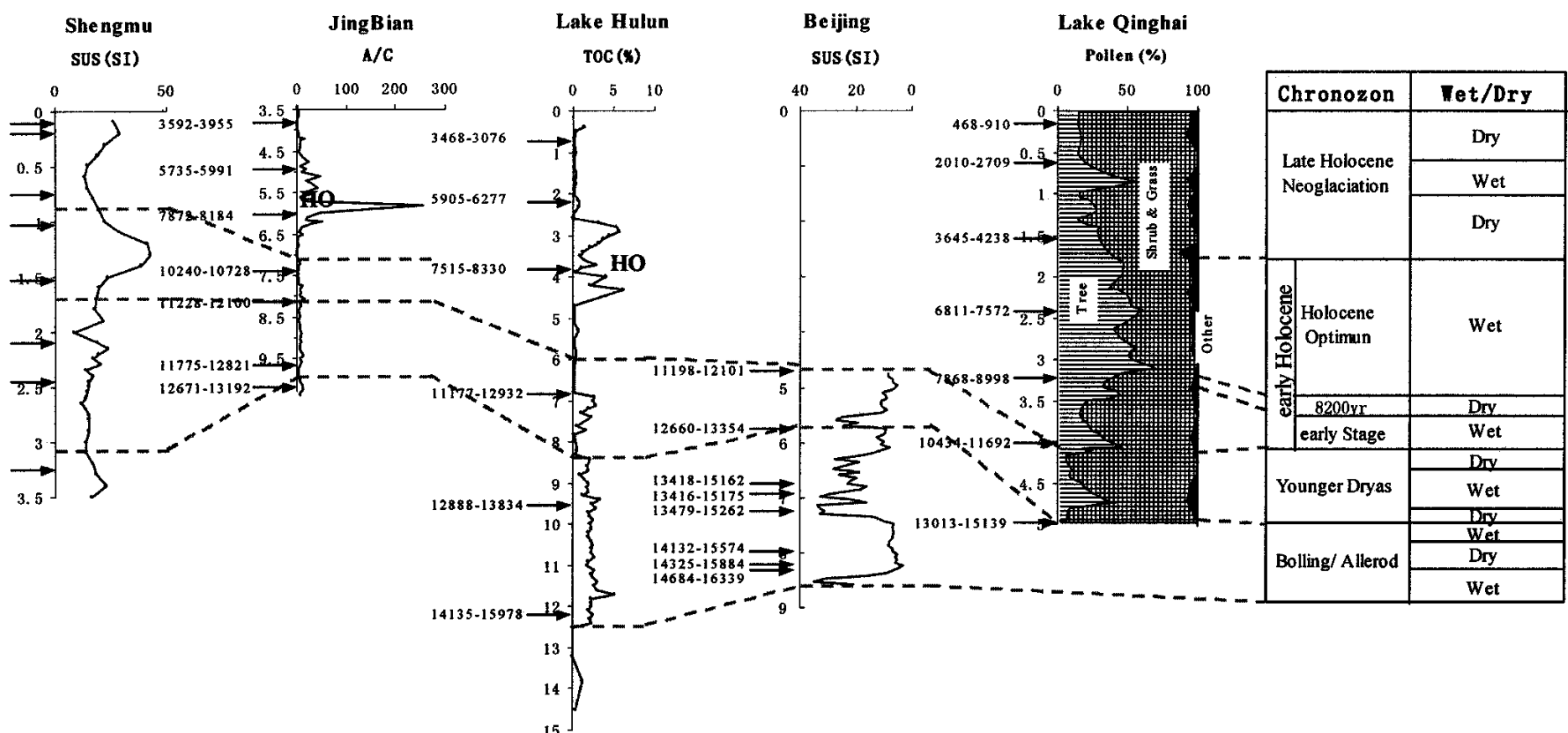

Figure 3 Climate proxies from four of the locations chosen from the arid to semi-arid zone. Distinctive climate change events have been chosen for comparison and dry and wet history was reconstructed. The dashed lines bracket the major Bølling/Allerød, the Younger Dryas and the Holocene (HO represents Holocene Optimum) intervals. Calibrated ages have been used for comparison. 
organic carbon content in Lake Hulun indicate a period of high precipitation though there is still an arid fluctuation (wet-dry-wet) within it. From around 11,200 to 10,000 BP (12,900-11,600 cal BP), the Younger Dryas cold period is represented. However, there are frequent secondary fluctuations. In northern China under a cold and dry Northern Hemisphere background, moisture levels fluctuated significantly. During the mid Younger Dryas, 10,500-10,300 BP, all the proxy indices (Zhou et al. 1996; Wei et al. 1997; Zhou et al. 1997, 1999) jumped from low levels to high peaks. Meanwhile, pollen percentages present in Lake Qinghai sediments indicate that the level of tree pollen reached around 45\% (Du et al. 1989). The TOC content in the Lake Hulun sediments, and pollen analyses indicate that the presence of the pioneer plant Betula which has adapted to a cool climate, was significantly elevated (Wang et al. 1995).

A high Artemisia to Chenopodiaceae ratio, and high SUS values, altogether indicate a more humid climate, further suggesting an increase in monsoon precipitation (Zhou et al. 1996, 1998, 1999). Hence the climate-environmental conditions changed from dry to wet and back to dry during the Younger Dryas period. During the early Holocene, 10,000-5000 BP (Zhou et al. 1994), all proxies have high values (Figure 3). Soils were formed in desert areas as shown in Cagelebulu profile. The Holocene Optimum (HO, 9000-5000 BP), produced warm and humid climatic conditions, except for an abrupt cooling event around $8200 \mathrm{cal}$ BP (7460 BP) with amplitude of cooling equal to half that of the Younger Dryas (Alley et al. 1997). During the late Holocene (5000 BP to the present; Zhou et al. 1994), pollen percentages from Lake Qinghai are reduced, indicating a cool and dry climate trend. Unfortunately, the other profile could not extend to the recent period as indicated in Lake Qinghai.

It is clear that climate change (especially dry and wet change) in the arid to semi-arid zone of China is controlled by the quantity of monsoon precipitation. The East Asian monsoon produces front precipitation, where cold air from cold high latitudes dominated by the North Atlantic Oscillation system (Hurrell 1995) interacts with warm moist air from the low latitude oceans producing precipitation. This results in dry and wet changes in arid to semi-arid China being simultaneous with global cold and warm events. Therefore local changes are basically related to global fluctuations. It is worth mentioning that in the Bølling/Allerød-Younger Dryas cycle, century to millennial fluctuations of dry and wet conditions in northern China are in response to global cold and warm changes, reflecting climate instability. Recent studies have indicated that the Younger Dryas event is not represented by the same conditions globally. Its spatial distribution or variation shows cooling in high latitudes (GRIP member, 1993) and warming in low latitudes (Beck et al. 1998) while the mid latitudes in China record a century scale cold-dry and cool-wet interchange. Such a spatial variation matches the observations of the recent 50-yr sea surface temperature trend (when the temperature increase trend occurs in the tropical Pacific, cooling occurs in the north Atlantic area) (Woodruff et al. 1987). This may be a result of ocean/atmosphere interactions. Thus, with global warming, the wet conditions occurring during the last deglaciation can be used as an historical analogue for the future prediction of arid/semi-arid transition zone climate change in China.

\section{SPATIAL VARIATIONS OF THE DESERT MARGIN AND THE INFLUENCE OF HUMAN IMPACT}

The desert margin shifts for the two climate extremes have been reconstructed for the northern Loess Plateau (Figure 4) on the basis of the above study and a collection of published data (Zhou et al. 1996, 1998; Dong et al. 1995). During the LGM, the desert margin shifted southward to a latitude of about $38^{\circ} \mathrm{N}$ (calculations based on the Ordos Plateau, dashed line), not far from the present day boundary $\left(38^{\circ} 2^{\prime} \mathrm{N}\right.$, solid line). At the same time, the sea level along eastern China was $150-160 \mathrm{~m}$ lower than present and the coastline was extended eastward some 800-1000 km (Wang 1995). During the early Holocene, the desert margin was shifted about $3^{\circ}$ in latitude northward $\left(\sim 41^{\circ} \mathrm{N}\right.$, dashed 


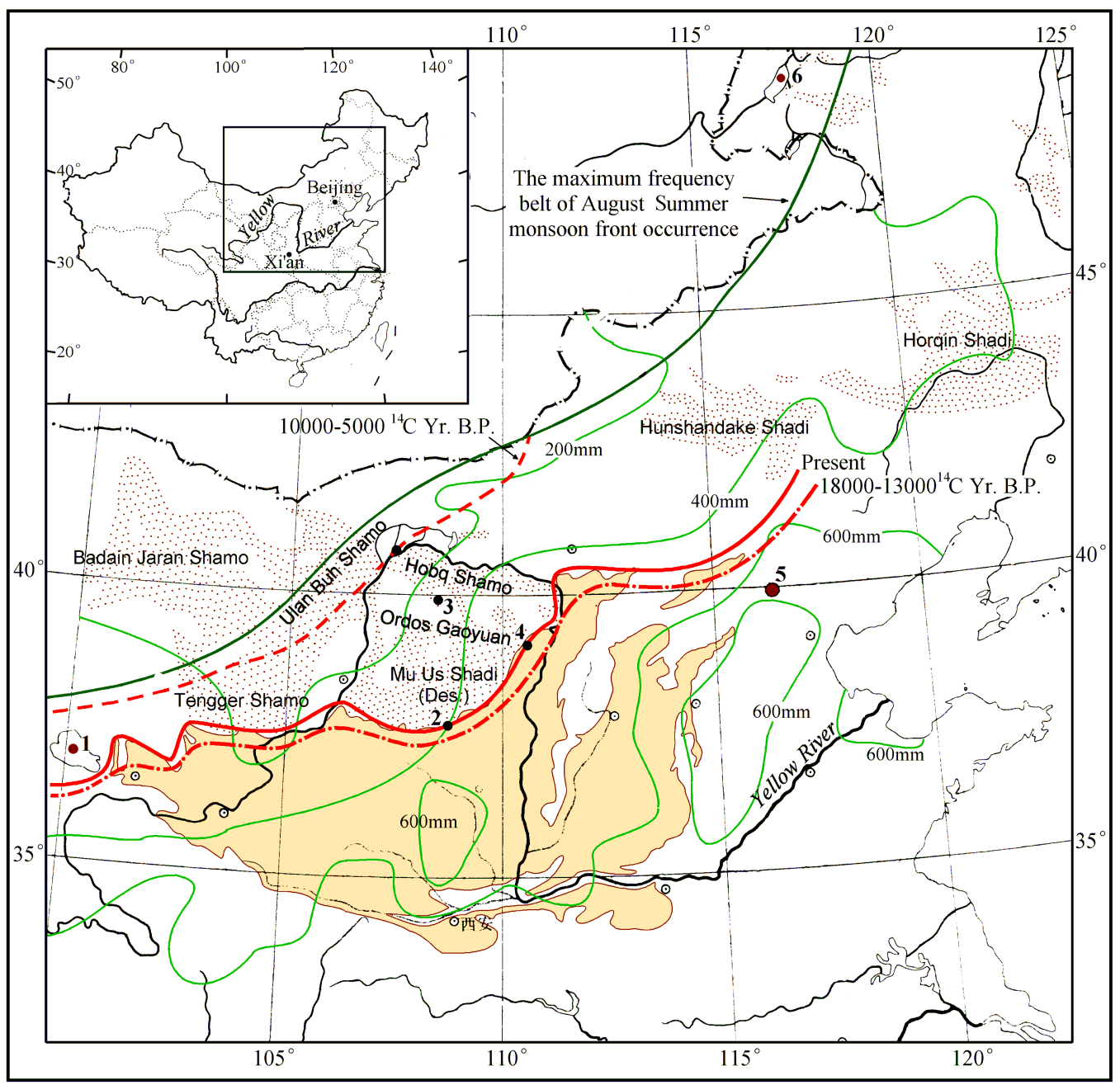

Figure 4 A suggested reconstruction of the desert/loess boundary positions. An inset map of China indicating the main study area is in the top left corner. The shaded area indicates the Loess Plateau, while stippled areas indicate deserts. Boundary positions during the last glacial maximum $\left(\sim 38^{\circ}\right.$, dashed line) and the early Holocene $\left(\sim 41^{\circ} \mathrm{N}\right.$, dashed line), and their relationship with the present day boundary $\left(38^{\circ} 21^{\prime} \mathrm{N}\right.$, solid line $)$ are indicated.

line Figure 4) on the Ordos Plateau. ${ }^{14} \mathrm{C}$ AMS determinations on soil organic matter ranged in value from $\sim 5000$ to $9000 \mathrm{BP}$, and magnetic susceptibility values were high. These higher values signify the presence of strengthened summer monsoon activity (Zhou et al. 1998). At this time, the extent of ice affected areas was reduced, and sea levels were higher than present (Wang 1995). The Mu Us Shadi (desert) was characterized by steppe environments (Zhu et al. 1986). except for one brief cold period, at 8200 BP (Alley et al. 1997).

In monsoonal China, precipitation is related to the position of the summer monsoon front (Gao 1962), which is at about $41^{\circ} 45^{\prime} \mathrm{N}$ in latitude, as shown in Figure 4. The latitudinal positions of the desert margin postulated for the periods from 9000 to 5000 and 21,000 to 15,000 years at about $41^{\circ} \mathrm{N}$ and $38^{\circ} \mathrm{N}$, respectively, are closely related to the position of the monsoon front (at present and LGM. 
An et al. 1992). The present desert margin is not far from that postulated for the LGM, yet the present monsoon front should have a greater similarity to that of the Holocene Optimum (see Figure 4). This discrepancy of about 3 degrees latitude allows us to test the hypothesis that human impact has influenced the position of the present desert margin considerably.

We can assume that the early Holocene climate $(10,000-5000 \mathrm{BP})$ in China was dominated by natural variability (Lin 1985). We assume that the present warm climatic condition is similar to that of the Holocene Optimum and that the present desert margin should be close to the location of the Holocene Optimum desert margin. We can then postulate that the southward shift of the present desert margin by about $3^{\circ}$ latitude may be a result of the impact of anthropogenic activity. This includes inappropriate land use causing desertification of these areas. During the Holocene Optimum, the Yangshao culture was developed (at around 7000-5000 BP). Advanced colored pottery making occurred in conjunction with primitive agriculture and domestic livestock management (Cao 1986; An 1987). From that time, this culture would not have survived if the environmental conditions were similar to those of today. During the late Holocene (5000 years to the present), the climatic condition was generally cold and dry.

At around 3000-2000 BP, the natural vegetation on the landscape was severely affected by an increase in human population (Cao 1986), dry farming activity, forest clearance, and frequent warfare (Wang 1985). Wind and water erosion became a problem, and desertification became intense. The grassland ecology in some places was modified to a semi-desert or desert environment, and mobile sand dunes were developed. The Hobq Shamo (desert) and Mu Us Shadi (sandy land) were combined and the area of desert increased. It has been estimated that the area of desertification within North China has increased to approximately $117,960 \mathrm{~km}^{2}$, occupying $57.0 \%$ of the total area (semi-arid to arid transition zone) since historical time, and especially during the last 300 years, based on LANDSAT-TM images and calculations (Zhu and Wang 1992). The Mu Us Shadi (desert) area has increased to $9400 \mathrm{~km}^{2}$ in the last 50 years, covering $24.8 \%$ of the total area (Wu and Ci 1998). There is now a clear picture of human activity as an external force, taking part in the natural environment change process. Hence, the influence of human activity must be taken into consideration when predictions of future environmental changes along this sensitive ecological boundary are made. Future ecological planning will need to take the two-way feedback between climate and anthropogenic impacts into account.

\section{ACKNOWLEDGMENTS}

This study was supported by NKBRSFG1999043400, NSFC49725308, 40023003 \& 49894170 , KZCX1-Y-05, KZCX2-108, and CAS KZ-951-A1-402, 2000-450. The authors are grateful to Professor S C Porter for guidance, Professor Yang Liping for the laboratory techniques, and NSF-AMS facility at Tucson, USA. We thank for the reviewer's valuable comments and suggestions.

\section{REFERENCES}

An ZS, Kukla, GJ, Porter, SC, and Xiao, J. 1991. Magnetic susceptibility evidence of monsoon variation on the Loess Plateau of central China during the last 130,000 years. Quaternary Research 36:29-36.

An ZS, Wu XH, Lu YC, Zhang DR, Sun XJ and Dong GR 1992. Study on environment change in China since 20,000 years. Number 2. Science Press. p 1-26.

An ZS, 2000. The history and variability of the East Asian paleomonsoon climate. Quaternary Science Review 19(1-5):171-87.
An ZM. 1987. The Neolithic age in western China. Archaeology Bulletin 2:133-51.

Alley RB, Mayewski PA, Sowers T, Stuiver M, Taylor KC, Clark TU. 1997. Holocene climate instability: a prominent, widespread event 8200 years ago. Geology 25:483-6.

Cao Z. 1986. History of the population of Shaanxi Province. Xi'an: San Qin Press. p 28-31.

Beck JW, Gagan M., Tudhope S, Récy J, Taylor F, Edwards RL, Cabioch G. 1998. Abrupt changes in early 
Holocene tropical sea surface temperature from coral $\mathrm{Sr} / \mathrm{Ca}, \mathrm{U} / \mathrm{Ca}$ and ${ }^{18} \mathrm{O}$ thermometry. In: Matsumoto $\mathrm{E}$, editor. Proceedings of the third international marine science symposium. Tokyo: Japan Marine Science Foundation. p 40-9.

Dong GR, Chen HZ, Wang GR, Li XZ, Shao YJ, Jing J. 1995. The evolution of desert and sandy land in North China and their climatic change in the last 150ka. Science in China (B)25:1303-12.

Du NQ, Kong ZC, Shan FS. 1989. Spore pollen analysis from Lake Qing Hai core QH85-14C and the discussion of its paleoclimate and environment. Acta Botanic Sinica 31:803-14.

El-Moslimany AP. 1990. Ecological significance of commom nonarboreal pollen: examples from drylands of the Middle East. Review of Paleobotany and Palynology 64:343-50.

Gao Y. 1962. Maximum summer monsoon frequency Problems related to the East Asian Monsoon. Beijing: Science Press. p 51-9.

GRIP member 1993. Climate instability during the interglacial period recorded in GRIP ice core. Nature 364: 203-7.

Hakansson S. 1985. A review of various factors influencing the stable carbon isotope ratio of organic lake sediments by the change from glacial to post glacial environmental conditions. Quaternary Science Review 4: 135-46.

Head MJ, Zhou WJ, Zhou MF. 1989 Evaluation of the ${ }^{14} \mathrm{C}$ ages of organic fractions from loess paleosol sequences near Xian China. Radiocarbon 31(3):680-94.

Hurrell JW. 1995. Decadal trends in the North Atlantic oscillation: regional temperatures and precipitation. Science 269:676-9.

Lin Q. 1985. Study on ecological-economic problems. Shanghai: People's Press. p 193-209.

Maher BA, Thompson R. 1991. Mineral magnetic record of the Chinese loess and palaeosol. Geology 19:3-6.

[RCNRE] Research Center of Natural Resources and Environment in Western China, Chinese Academy of Sciences, Lanzhou Branch of Chinese Academy of Sciences. 1994. The evolution of recent environment of Lake Qinghai and prediction. Beijing: Science Press. p 225-39.

Slota PJ Jr, Jull AJT, Linick TW, Toolin LJ. 1987. Preparation of small samples for ${ }^{14} \mathrm{C}$ accelerator targets by catalytic reduction of CO. Radiocarbon 29(2):303-6.

Stuiver M, Reimer B, Braziunas T. 1998. High-precision radiocarbon age calibration for terrestrial and marine samples. Radiocarbon 40(3):1127-51.

Wang SM, Ji L. 1995. Lake Hulun: study on paleolimnology. Hefei. University of Science and Technology Press, China. p 87-93.

Wang PX. 1995. The role of the West Pacific marginal seas in glacial aridification of China. Quaternary Sciences 1:32-42.

Wang SY. 1985. Transition of agriculture and animal husbandry on the Ordos Plateau during historical periods and its influence on the natural environment. Historical Geography 5:11-24.

Wei LY, Peng G, Yan FH, Yi JH, Lu YC, Liu RM. 1997. The preliminary study of last deglaciation climate and environment change in Beijing. Quaternary Sciences 2:183-91.

Woodruff S, Slutz R, Jenne R, Steurer R. 1987. A comprehensive ocean-atmosphere data set. Journal of the American Meteorological Society 68:1239-50.

Wu B, Ci LJ. 1998. The developing situation and expanding causes of desertification in Mu Us sandy land since the 1950's. Quaternary Sciences 2:165-72.

Yie DZ. 1992. Prestudy of global change in China. Beijing: Meteorological Press. p 1-18.

Zhou WJ, Donahue DJ, Porter SC, Jull AJT, Li XQ, Stuiver M, An ZS, Matsumoto E, Dong GR. 1996. Variability of monsoon climate in East Asia at the end of the last glaciation. Quaternary Research 46:21929.

Zhou WJ, Head MJ, Lu XF, An ZS, Jull AJT, Donahue DD. 1999. Teleconnection of climatic events between East Asia and polar, high latitude areas during the last deglaciation. Palaeogeography, Palaeoclimatology, Palaeoecology 152:163-72.

Zhou WJ, Donahue D, Jull AJT. 1997. Radiocarbon AMS dating of pollen concentrated from eolian sediments: implications for monsoon climate change since the late Quaternary. Radiocarbon 39(1):19-26.

Zhou WJ, An ZS, Jull AJT, Donahue DJ, Head MJ. 1998. Reappraisal of Chinese Loess Plateau stratigraphic sequences over the last 30,000 years. Radiocarbon 40(2):905-13.

Zhou WJ, An ZS, Head MJ. 1994. Stratigraphic division of Holocene loess in China. Radiocarbon 36(1):3746.

Zhu ZD, Wang T. 1992. The theory and practice of Chinese desert research. Quaternary Sciences 5: 97-106.

Zhu ZD, Liu S, Wu Z, Di XM. 1986. Desert in China. Lanzhou Institute of Desert Research, Academia Sinica Press. p 1-80. 